\title{
Penegakan Hukum Lingkungan Atas Pembuangan Limbah Plastik Di Indonesia
}

\author{
Maria Ibella Vianka \\ Fakultas Hukum, Universitas Tarumanagara
}

dikirim: 10 Oktober 2021 direvisi:31 Desember 2021 diterima: 31 Desember 2021

\begin{abstract}
Abstrak:
Indonesia merupakan negara nomor dua sebagai penyumbang limbah plastik terbanyak setelah negara China. Ditemui, sebanyak 187,2 ton sampah menggenang di laut Indonesia. Limbah plastik yang ada di lautan, mengancam ekosistem biota laut dan kehidupan manusia. Diprediksi bahwa pada tahun mendatang, sumber pangan manusia lebih banyak dikontribusi dari laut. Permasalahan ini perlu dijadikan poin utama negara dalam hal pencegahan kerusakan lingkungan hidup. Negara Indonesia sudah mengatur peraturan mengenai lingkungan yang tertuang dalam UU PPLH Dalam mencegah permasalahan tersebut, perlu dilakukan upaya pengawasan oleh para aparat penegak hukum di masyarakat. Namun, ditemui upaya pengawasan di lapangan sebagai tindak upaya pencegahan tidak dilakukan secara maksimal, sanksi yang diterapkan tidak tegas membuat masyarakat dan pelaku usaha tidak mengindahkan aturan hukum yang telah dibuat. Penegakan hukum lingkungan dilakukan dengan tiga instrument hukum yaitu sanski administratif, ranah perdata dan ranah pidana. Berkaca dari negara maju, seperti contohnya negara tetangga Singapura, sudah seharusnya Indonesia menerapkan aturan hukumnya secara tegas, mengingat upaya menjaga lingkungan adalah hal mendasar untuk menciptakan negara di dalamnya menjadi tempat yang nyaman. Dalam menjaga lingkungan Negara Indonesia, sudah seharusnya pemerintah bertindak tegas dalam pemberlakuan hukumnya dan menerapkan aturan hukum yang baru yaitu berupa sanksi denda yang dapat diterapkan di masyarakat dan sudah seharusnya menjadi prioritas utama negara untuk menjaga negara bebas dari limbah plastik di lautan.
\end{abstract}

Kata Kunci : Aturan Hukum Indonesia, Limbah Plastik, Penegakan Hukum Lingkungan.

\begin{abstract}
:
Indonesia is the second largest contributor to plastic waste after China. It was found, as much as 187.2 tons of garbage pooled in Indonesian seas. Plastic waste in the oceans threatens marine biota ecosystems and human life. Prediction that in the coming year, more human food sources will be contributed from the sea. This problem needs to be the main point of the state in terms of preventing environmental damage. The State of Indonesia has regulated the oldest environment in the PPLH Law. In preventing these problems, it is necessary to carry out surveillance efforts by law enforcement officers in the community. However, supervision efforts in the field as a preventive measure are not carried out optimally, the sanctions applied are not firm, making the community and business actors not heed the legal rules that have been made. Enforcement of environmental law is carried out with three legal instruments, namely administrative sanctions, civil matters and criminal matters. Reflecting on developed countries, such as the neighboring country of Singapore, Indonesia should apply the rule of law strictly, considering that efforts to protect the environment are fundamental to making the country in it a comfortable place. In protecting the environment of the State of Indonesia, the government should act decisively in enforcing the law and implementing new legal rules, namely in the form of fines that can be applied to the community and should be the main priority of the state to keep the country free from plastic waste in the oceans.
\end{abstract}

Keywords : Indonesian Law, Plastic Waste, Environmental Law Enforcement. 


\section{PENDAHULUAN}

Tata kelola lingkungan hidup yang baik demi pembangunan berkelanjutan harus menjadi perhatian penting bagi setiap orang agar lingkungan tetap terjaga. Berdasarkan riset Jenna Jembeck Universitas Georgia, US, Indonesia merupakan negara kedua penyumbang sampah plastik 187,2 ton sampah di lautan setelah negara China (CNN, 2016). Dari permasalahan ini, tidak ada upaya penegakan yang tegas dari pemerintah sendiri. Limbah plastik yang mengapung di lautan mengancam berbagai aspek kehidupan, tentunya mengancam hewan dan biota laut, sampai aspek kehidupan manusia, untuk itu, diperlukan upaya penegakan hukum yang tegas dan upaya penerapan hukum baru dari pemerintah sebagai upaya mencegah pencemaran dan kerusakan lingkungan. Diprediksi pada tahun 2048 dari data Badan Pangan Dunia dikemukakan bahwa, sumber makanan manusia dikontribusi dari lautan (BeritaSatu, 2020).

Realita akan Penegakkan Hukum atas pembuangan limbah yang didominasi sampah plastik sangat tidak tegas. Permasalahan tadi sudah membuktikan bahwa isu lingkungan tidak menjadi hal utama bagi pemerintah dalam menjaga lingkungan Negara. Ditemui bahwa sumber sampah plastik yang ada di lautan didominasi dari daratan yang mengalir melalui sungai ke lautan (Darilaut.id, 2019). Hal ini menunjukkan bahwa kesadaran di kalangan masyarakat masih sangat kurang dan tidak taat dalam menjaga kebersihan lingkungan negara. Para aparat diharapkan mampu mengatasi permasalahan yang ada demi mencegah kerusakan lingkungan hidup. Masih banyak aparat yang tidak tegas dan kurang mengoptimalkan fungsi pengawasan di lapangan (Rizal, 2017). Aturan untuk menjaga lingkungan hidup sudah tertuang dengan jelas di dalam Undang-undang Perlindungan dan Pengelolaan Lingkungan Hidup , tetapi dalam praktiknya tidak berjalan secara harmonis dan konsisten. Upaya dalam penegakan hukum lingkungan dilakukan berupa sanksi administrative, ranah perdata dan ranah pidana (Handayani I, 2010). Upaya penegak hukum yang telah ada, masih belum cukup untuk mengatasi permasalahan negara kita sebagai penyumbang limbah plastik di lautan. Mengambil contoh dari negara maju Singapura, yang sudah mampu menerapkan sanksi tegas berupa denda di kalangan masyarakatnya, diharapkan mampu menciptakan negara bebas limbah plastik yang selama ini tindakan tegas berupa denda di masyarakat Indonesia masih belum berlaku tegas dan belum 
Morality: Jurnal Ilmu Hukum

diterapkan, khususnya di area-area sempit, di jalanan dan lingkungan perumahan.

Rumusan masalah yang diteliti oleh penulis adalah merumuskan tentang bagaimana penegakan Hukum Lingkungan atas pembuangan limbah plastik di Indonesia sesuai dengan Undang-Undang No. 32 Tahun 2009 tentang Perlindungan dan Pengelolaan Lingkungan Hidup, dengan mengambil tujuan penelitian dengan menganalisis realitas penegakan Hukum Lingkungan atas pembuangan limbah plastik di Indonesia.

Metode penelitian dalam makalah ini yaitu menggunakan metode normatif dan empiris. Penelitian hukum dari segi normatif empiris yang digunakan yaitu mengenai implementasi ketentuan hukum normatif yang bersumber dari Peraturanperaturan tertulis yaitu UU PPLH, dan dengan penelitian empiris berdasarkan permasalahan di lapangan. Dalam artikel ini, penulis menganalisis mengenai realitas penegakan Hukum Lingkungan atas pembuangan limbah plastik di Indonesia dan bagaimana penegakan hukum nya di lapangan berdasarkan permasalahan yang ada. Jenis data yang penulis ambil adalah data kuantitatif terkait presentase dan besar jumlah limbah yang ada di Indonesia dengan mengacu pada dominannya angka limbah yang dibuang di Indonesia yaitu limbah plastik, penulis menggunakan
Desember 2021, Volume 7 Nomor 2

teknik pengumpulan data dengan studi pustaka dan studi dokumen yang berasal dari buku, sumber-sumber berita, jurnaljurnal dan website yang berkaitan dengan penelitian penulis, dan teknik pengolahan data pada makalah ini adalah tentang analisis yang menghubungkan permasalahan akan realitas yang ada dengan peraturan dari Undang-Undang Lingkungan yang tidak berjalan secara sistematis.

\section{PEMBAHASAN}

\section{A. Penyebab Banyaknya Limbah Plastik di Laut Indonesia}

Banyaknya limbah plastik di lautan Indonesia sangat mengkhawatirkan. Limbah plastik yang menjadi pencemaran Laut Indonesia mengendap di lautan, karena sifat dari bahan plastik adalah bahan yang sulit terurai secara alamiah. Bahan plastik tidak hanya mampu mencemari lingkungan, tetapi berbahaya kepada manusia juga. Proses produksi plastik menghasilkan emisi karbon yang tinggi yang mana bisa menyebakan pencemaran di udara. Limbah- limbah plastik yang tidak diolah atau dikelola pembuangannya secara beriringan dengan perilaku masyarakat yang abai akan mencemari pencemaran di sungai yang mengakibatkan tersumbatnya badan air, termakan oleh hewan laut yang mana membahayakan sumber utama makanan 
Morality: Jurnal Ilmu Hukum

kita, dan merusak ekosistem di sungai dan laut (Dietkantongplastik.info, 2017).

Permasalahan limbah tidak akan pernah selesai jika tidak ada kesadaran dari masyarakat, pihak swasta maupun penegakan hukum atas pembuangan limbah di Indonesia. Penyebab Banyaknya Limbah Plastik yang menggenang di Laut Indonesia, disebabkan oleh Budaya Masyarakat yang sudah melekat dalam hal abainya menjaga lingkungan dengan membuang limbah sembarangan. Menurut Teori Perilaku yang dikemukakan oleh Lawrence Green, faktor perilaku masyarakat membuang limbah secara sembarangan disebabkan oleh 3 faktor yaitu, faktor predisposisi yang berasal dari individu untuk melakukan Tindakan yaitu pengetahuan, faktor pemungkin yang berasal dari luar diri tiap individu, misalnya ketidaktersediaan tempat penampungan limbah, yang terakhir yaitu faktor penguat yang berasal dari luar individu, misalnya dari orang lain yang sama-sama abai dan terbiasa membuang limbah secara sembarangan, sehingga individu akan mencontoh perilaku individu yang lain (wanaswara.com, 2017).

Faktor penyebab terhadap pembuangan limbah secara sembarangan di kalangan masyarakat akan terus terjadi, dampak yang ditimbulkan juga bertimbal balik kepada manusia. Faktor-faktor penyebab
Desember 2021, Volume 7 Nomor 2

tersebut diakibatkan karena lemahnya Penegakan Hukum soal pembuangan limbah secara sembarangan. Menyoroti hal ini, Sekretaris Jenderal Inaplas Fajar Budiyono, mengemukakan tentang manajemen atau implikasi terhadap proses alur pembuangan dari rumah tangga sampai kepada Tempat pembuangan akhir masih belum ada upaya signifikan dari pemerintah, Law Enforcement akan pembuangan limbah perlu dipertegas di kalangan masyarakat yang bukan hanya terpaut kepada regulasi semata yang ada (Hana, 2017).

Selain dari faktor di kalangan masyarakat, penegakan Hukum di kalangan pihak swasta juga perlu adanya mekanisme tegas, dimana penggunaan plastik masih diterapkan di tempat pasar tradisional, tempat makan, dan tempat perbelanjaan. Karena itu, penyebab / faktor permasalahan pembuangan limbah plastik yang tidak kunjung selesai dimana mencemari lautan di Indonesia diperlukan Tindakan yang serius dari berbagai kalangan, mengingat Indonesia adalah negara yang kaya akan potensi laut dan perikanannya yang dapat mendukung perekonomian bangsa dan kesejahteraan masyarakatnya.

\section{B. Realitas Penegakan Hukum \\ Lingkungan atas pembuangan \\ limbah plastik di Indonesia}


Morality: Jurnal Ilmu Hukum

Dari realita yang penulis temukan dan berdasarkan data yang penulis analisis dalam makalah ini, bahwa negara kita, Indonesia dalam menjaga dan mempertahankan akan penegakan hukum terkait hukum lingkungan di Indonesia masih perlu tindakan tegas dari berbagai aparat, lemahnya akan penegakan hukum dalam menjaga lingkungan terkait banyaknya sampah-sampah plastik di lautan dilihat dari data bahwa Indonesia berada di posisi kedua dalam hal menyumbang sampah plastik di lautan setelah negara besar China. Pemaparan dari Christine Halim seorang ketua umum asosiasi daur ulang, mengatakan bahwa sampah masih menjadi persoalan di Indonesia karena aspek law enforcement / penegakan hukum akan lingkungan masih belum kuat. Nyatanya, instrumeninstrumen demi menegakan hukum lingkungan juga belum dijalankan secara faktual di lapangan. (Merdeka.com, 2018). Dari data yang menunjukkan bahwa banyaknya sampah plastik yang ada di laut Indonesia, menjadi bukti penegakan hukum Lingkungan di Indonesia tidak berjalan secara maksimal. Menyoroti hal ini, dampak dari limbah plastik di laut Indonesia mengancam berbagai aspek mulai dari rusaknya ekosistem laut, mengganggu pariwisata, mengganggu produktifitas nelayan dan mengancam
Desember 2021, Volume 7 Nomor 2

kesehatan ikan dan warga pesisir di sekitar wilayahnya karena lingkungan mereka tercemar sampah. Hal ini didukung dari data sumber Badan Pangan Dunia yang menyebutkan pada tahun 2048 mendatang, sumber pangan di negara kita bersumber dari laut, yang mana sumber kebutuhan makanan kita berasal dari hewan-hewan laut yang dapat berpotensi mengancam kesehatan manusia jika sumber pangan terkontaminasi oleh hasil pembuangan limbah.

Menurut Nani Hendiarti yang mengkaji dalam bidang ilmu kemaritiman dengan Bank Dunia, diketahui sebanyak $80 \%$ sampah di laut berasal dari daratan yang mengalir ke lautan. Permasalahan ini harus dibenahi dari sumbernya dahulu, yaitu bagaimana target pemerintah untuk menangani pemulihan pencemaran air demi menjaga kelestarian lingkungan dan mencegah pencemaran di laut sebagaimana tertuang dalam UU PPLH, sebagai aparat negara yang mempunyai wewenang menindak para pelanggar ketentuan pencemaran lingkungan harus mempunyai sikap tegas dan memantau para pelanggar agar menjaga lingkungan negara dengan sebaik-baiknya. Namun nyatanya, aspek yang menghambat implementasi pencemaran air adalah tidak maksimalnya sistem pengawasan itu sendiri akan penegakan hukum lingkungan kita, dalam 
Morality: Jurnal Ilmu Hukum

kaitannya, pengawasan yang tidak rutin yang sudah seharusnya dilakukan oleh para aparat di lapangan tidak dilakukan dengan maksimal, dokumentasi data yang tidak lengkap serta sumber informasi dalam melakukan pengawasan yang kurang terbuka. (Herlina N).

Di dalam UU PPLH, tepatnya pada pasal 13, pengendalian pencemaran lingkungan hidup dilaksanakan oleh pemerintah, pemerintah daerah, dan penanggung jawab sesuai dengan kewenangan, peran, dan tanggung jawabnya masing-masing yang meliputi 3 pengaturan yaitu dimulai dari pencegahan, penanggulangan dan pemulihan. Namun hal ini tidak ditemui dan masih banyak apparat yang tidak tegas dalam melakukan pengawasan dalam 3 pengaturan tadi. Jika masih ditemui sampah di selokan dari hasil pembuangan limbah contohnya limbah tekstil / pabrik / limbah rumah tangga, sudah seharusnya para kegiatan usaha / masyarakat bertanggung jawab dalam hal pengelolaannya, tentunya sumber utama ini harus dibenahi dan ditindak secara tegas sebagai bentuk pelanggaran. Sejalan dengan UU No. 18 Tahun 2008 tentang Pengelolaan Sampah, di dalam pasal tersebut disebutkan bahwa setiap orang dilarang untuk membuang limbah ke dalam wilayah NKRI, mengimpor sampah, dan membuang sampah sembarangan
Desember 2021, Volume 7 Nomor 2

sebagai bentuk tanggung jawab bersama dalam menjaga kelestarian wilayah tempat tinggal. Hal ini dapat kita temui, masih belum ada aturan yang tegas akan pelanggaran bagi siapa saja yang membuang limbah secara sembarangan ke wilayah NKRI, dan sanksi membuang sampah secara sembarangan masih belum tegas.

Dengan tujuan pembentukan UU PPLH di Indonesia dalam peraturan dan ketentuan agar setiap orang menjaga lingkungan, nyatanya para aparat penegak hukum kita terbukti belum optimal dalam melakukan pengawasan dan tindakan hukumnya yang tidak berjalan secara terus menerus dan cenderung bukan menjadi prioritas utama pemerintah, hal ini dibuktikan dalam Peraturan Presiden RI No. 7 Tahun 2005 tentang permasalahan lingkungan hidup di Indonesia yaitu habitat ekosistem pesisir dan laut semakin rusak, tingkat pencemaran air yang meningkat, dan pengelolaan limbah yang tidak diaplikasikan di lapangan. Sangat rendahnya kesadaran masyarakat dan para pelaku usaha akan pembuangan limbah masih perlu tindakan yang tegas dari pemerintah untuk mencegah pelanggaran lingkungan ini.

Dari ketiga upaya dalam penegakan hukum lingkungan, yaitu sanksi administratif sebagai solusi pertama, 
Morality: Jurnal Ilmu Hukum

hukum perdata dan hukum pidana. Untuk meningkatkan kesadaran masyarakat dan pelaku usaha, sanksi administrative ini melingkupi pengenaan sanksi terhadap berbagai pelanggaran jika menyebabkan kerusakan lingkungan yang membahayakan keselamatan dan kesehatan manusia, pelanggaran yang melanggar ketentuan izin lingkungan, pelanggaran atas dugaan pemalsuan dokumen persyaratan, dan pelanggaran yang berkaitan dengan izin usaha.

Realitas penegakan hukum pembuangan limbah dalam penjatuhan sanski administratif nyatanya juga tidak tegas dan tidak konsisten, banyak pelaku usaha yang tidak taat dalam melakukan tanggung jawabnya. Diketahui pula bahwa realitas penegakan hukum lingkungan terkait pembuangan limbah tidak diberikan sanksi, banyak terjadinya kelonggaran dalam pemberian sanksi administratif. Menurut pengajar Hukum Lingkungan Program Doktor Ilmu Hukum Undip, Adji Samekto mengatakan penegakan hukum masih tataran konsep yang belum dilakukan secara nyata, ditemukan para pelaku industri terbukti merusak lingkungan yang mana sudah seharusnya ditindak upaya hukum (Kompas.com, 2009).

Mengingat isi Pasal 33 ayat (3) UUD 1945, masyarakat Indonesia perlu menjaga
Desember 2021, Volume 7 Nomor 2

wilayah NKRI dengan sebaik-baiknya sebagai negara kedua terbesar dalam penyumbang limbah, yang dapat mengakibatkan masalah sosial-ekonomi negara. Penegakan hukum menjadi kunci yang utama untuk menjaga lingkungan NKRI. Aturan yang sudah dimuat agar warga masyarakat dan pelaku usaha dalam hal menjaga lingkungan telah sudah lama ada, tetapi pada kenyataannya, aturan tersebut tidak berjalan secara maksimal. Penegakan hukum ini, tentunya tidak lepas dari para aparat yang sudah seharusnya memantau kondisi di lingkungan dan mengambil langkah yang efektif untuk memperbaiki persoalan limbah plastik di Indonesia.

Penegakan hukum yang dilakukan para aparat dengan pengawasan di lapangan bertujuan untuk memantau ketaatan para pelaku jika sewaktu-waktu terjadi pelanggaran lingkungan hidup (Pinilih, 2015). Penegakan hukum yang dianut dalam UU PPLH Pasal 53 (2), terkait penanggulangan pencemaran kerusakan lingkungan dalam hal membuang limbah secara sembarangan dapat dilakukan dengan pemberian peringatan dari warga masyarakat di lingkungan, sampai ke pelaku usaha, agar masyarakat dan para pelaku usaha menjadi sadar dan taat dalam menjaga lingkungan agar tidak sewenang-wenang dalam 
Morality: Jurnal Ilmu Hukum

membuang limbah hasil rumah tangga maupun hasil produksi. Hal ini pun perlu tindakan yang konsisten dari para aparat hukum untuk menyadarkan warga masyarakat maupun para pelaku usaha. Dalam menegakkan hukum lingkungan untuk mengurangi jumlah limbah plastik di Indonesia dari segi hukum, dapat dilakukan upaya hukum yaitu upaya hukum administrasi, hukum perdata dan hukum pidana yang diatur dalam UU PPLH yang dapat diterapkan.

\section{Langkah Penegakan Hukum Lingkungan atas pembuangan limbah plastik di Indonesia}

Upaya atau langkah-langkah penegakan hukum lingkungan yang pertama adalah penerapan sanksi administratif, sanksi ini diatur dalam Pasal 25, 26, dan Pasal 27 yaitu yaitu pemberian teguran tertulis kepada pelaku usaha dalam hal kerusakan lingkungan yang ditimbulkan, paksaan dari pemerintah, pembekuan dan pencabutan izin lingkungan kepada para pelaku usaha, dan sanksi denda bagi yang melanggar ketentuan dalam UU PPLH. Paksaan pemerintah berupa penghentian sementara kegiatan produksi sampai kepada penyitaan. Pembekuan izin lingkungan dan Pencabutan izin lingkungan dapat diterapkan kepada siapa saja bagi yang tidak melaksanakan sanksi administratif
Desember 2021, Volume 7 Nomor 2

paksaan pemerintah yang mengakibatkan pencemaran dan meresahkan masyarakat. Upaya kedua dalam ranah perdata, yang diatur dalam Pasal 34 dan Pasal 35 dapat ditempuh melalui pengadilan maupun cara mediasi dalam hal ini telah terjadi perselisihan hubungan hukum dengan kepentingan perseorangan. Upaya ketiga dalam ranah pidana yang diatur dalam Pasal 41, 42, 43, 44, 45, 46, dan 47 berupa ancaman minimum dan maksimum dalam hal pemidanaan kepada siapa saja yang melanggar untuk menegakan hukum lingkungan (Korompis A, 2018).

Penegakan hukum lingkungan atas pembuangan limbah plastik di Indonesia harus dan perlu ditegakan oleh pemerintah Indonesia dalam hal ini demi mencegah dampak kesehatan yang mempengaruhi kondisi sosial dan ekonomi bangsa serta lingkungan laut bangsa Indonesia. Melihat realita sebagai negara kedua terbanyak penyumbang limbah plastik di dunia, penegakan hukum lingkungan terbukti tidak diupayakan secara maksimal dan penegakan hukumnya masih sangat lemah, walaupun konsep dan peraturan sudah tertulis dan tertuang, nyatanya di lapangan tidak diupayakan secara maksimal. Hal ini perlu menjadi perhatian besar dari pemerintah dan aparat penegak hukum demi menegakan hukum di lingkungan masyarakat maupun kegiatan perindustrian 
Morality: Jurnal Ilmu Hukum

yang mana tujuan Indonesia sebagai negara bebas plastik bisa terwujud.

Dalam Penyelesaian Sengketa akan Lingkungan Hidup yang dapat mengakibatkan dan merugikan banyak pihak, dapat diupayakan. Penyelesaian Sengketa akan Lingkungan Hidup juga diatur dalam UUPLH dalam Pasal 30. Di dalam Pasal tersebut diatur mengenai penyelesaian sengketa lingkungan hidup dapat ditempuh melalui pengadilan / diluar pengadilan. Dalam penyelesaian sengketa di luar pengadilan dapat menggunakan jasa pihak ketiga sesuai dalam Pasal 32 UUPLH, yang mana pihak ketiga mempunyai wewenang untuk mengambil keputusan untuk membantu penyelesaian sengketa. Selain itu dapat dalam Pasal 33 UUPLH, pemerintah / masyarakat dapat membentuk Lembaga penyedia jasa penyelesaian sengketa lingkungan hidup yang bersifat bebas dan tidak memihak.

Dalam Penyelesaian sengketa melalui pengadilan, dapat berupa gugatan ganti kerugian yang mana gugatan tersebut di proses ke Pengadilan Tata Usaha Negara. Gugatan ke Pengadilan Umum dilakukan dapat dilakukan sesuai dengan ketentuan Pasal 34 dan 35 UUPLH yaitu mengenai gugatan ganti kerugian, gugatan class action berdasarkan ketentuan Pasal 37, dan gugatan legal standing sesuai peraturan Pasal 38. Di dalam Pasal 34,
Desember 2021, Volume 7 Nomor 2

menganut asas liability based on fault yang menjadi tanggung jawab korban selaku penggugat untuk membuktikan adanya kerugian atas pencemaran lingkungan yang dialaminya. Di dalam Pasal 35, menganut asas strict liability yang mana dalam pembuktian, yang dibebani adalah tergugat dalam hal pelaku tindak pencemaran lingkungan (Harahap, 2004).

Penegakan hukum lingkungan atas pembuangan limbah plastik di Indonesia, sudah seharusnya pemerintah mengambil langkah-langkah yang dapat dimulai secara sederhana yang selama ini tidak ada peraturan sanksi atau denda kepada masyarakat yang membuang limbah di jalanan, akses-akses sempit dan tidak terjangkau. Berkaca pada negara maju seperti Singapura yang sudah menerapkan hukum lingkungan, setelah negara Singapura merdeka dilakukan dengan berbagai kampanye untuk membuat negaranya tetap bersih, hukum lingkungan yang sudah diterapkan yaitu menerapkan sanksi berupa denda. (BBC, 2021). Dalam hal ini, pembuangan limbah yang dilakukan secara sengaja, membuat warga negara Singapura menjadi lebih sadar akan dampak terhadap negaranya. Upaya pemerintah tersebut terbukti menjaga moral tetap tinggi, kesehatan dan kondisi sosial serta pertumbuhan ekonomi yang mendorong industri dan pariwisata mereka 
Morality: Jurnal Ilmu Hukum

terus meningkat. Langkah pemerintah juga dinilai efektif menciptakan masyarakat perduli akan lingkungan karena penegakan hukumnya mengatur secara tegas. Untuk itu, negara Indonesia perlu ikut mengambil langkah yang baru untuk mendorong masyarakat dan pelaku usaha dan menindak dengan tegas dalam hal memberlakuan sanksi baik itu pengawasan atau denda sebagai negara hukum yang mampu menjaga lingkungan negaranya tetap terjaga dan bebas dari limbah plastik.

\section{KESIMPULAN}

Upaya hukum lingkungan di Indonesia yang tidak tegas, mempengaruhi lemahnya kesadaran masyarakat dan para pelaku industri dalam menjaga lingkungan negara. Selama ini belum ada peraturan terkait sanksi denda jika membuang limbah secara sembarangan seperti di tempat sempit atau di jalan-jalan raya. Berbagai peraturan dan upaya pemerintah yang tidak tegas dibuktikan dengan realitas di lapangan yang mana peraturanperaturan tersebut hanyalah teguran belaka yang mengakibatkan lautan di Indonesia menjadi penuh sampah yang sebagian besar berasal dari sungai yang mengalir ke laut.

Hal ini tentunya berdampak kepada aspek kesehatan lingkungan yang semakin kotor, pencemaran air, dan mempengaruhi kesehatan manusia. Melihat realita yang
Desember 2021, Volume 7 Nomor 2

ada, diperlukan upaya tegas dari pemerintah baik itu sanski administrative, sanksi pidana dan sanski perdata yang perlu ditegakan oleh pemerintah dan para penegak hukum. Upaya yang tegas dari pemerintah diharapkan dapat mengubah stigma Indonesia menjadi negara bebas limbah plastik, negara hukum yang tegas akan penegakan hukum lingkungannya diharapkan mampu meningkatkan kesadaran masyarakat dan para pelaku usaha terhadap dampak limbah plastik bagi negara sesuai tujuan dan amanat di dalam UU PPLH di Indonesia dalam peraturan dan ketentuan agar setiap orang menjaga lingkungan negaranya.

\section{DAFTAR RUJUKAN}

Biro Komunikasi (2021). Bahas Target Pengurangan Sampah Di Indonesia, Deputi Nani:Perlu Klaborasi Uji Komprehensif. Diakses Pada 3 November 2021, Dari Https://Maritim.Go.Id/Bahas- TargetPengurangan-Sampah-IndonesiaDeputi-Nani-Perlu.

Hana, O D B, (2020). Atasi Problem Sampah, Penegakan Hukum Perlu Dilakukan. Diakses Pada Diakses Pada 17 November 2021, Dari Https://Ekonomi.Bisnis.Com/Read/20 200108 /257/1188218/Atasi-ProblemSampah- Penegakan-Hukum-PerluDilakukan.

Handayani, I. (2010). Peranan Sanksi Administrasi Dalam Penegakan Hukum Lingkungan Di Indonesia. Pranata Hukum. 1 (5). 39-46. 
Harahap, Z. (2004). Penegakan Hukum Lingkungan Menurut Uuplh. Jurnal Hukum No. 27 Vol 11. 7-22.

Herlina, N S. Permasalahan Lingkungan Hidup Dan Penegakan Hukum LingkunganDi Indonesia. Dosen Tetap, Fakultas Hukum, Universitas Galuh.

Https://Www.Dw.Com/Id/Sampah-

Mengalir- Sampai-Laut-BagaimanaPemerintah- Kesulitan-BersihkanSungai/A-47196994. Sampah Mengalir Sampai Laut - Bagaimana Pemerintah Kesulitan Bersihkan Sungai. Diakses Pada 3 November 2021.

Https://Idtesis.Com/Faktor-Faktor-Yang-

Mempengaruhi-Perilaku-Masyarakat-

Dalam-Membuang-Sampah/. FaktorFaktor Yang Mempengaruhi Perilaku Masyarakat Dalam Membuang Sampah. (2019). Diakses Pada 3 November 2021.

Https://Dietkantongplastik.Info/Bahaya-

Kantong-Plastik/. Bahaya Kantong Plastik. Diakses Pada 17 November 2021.

Https://Wanaswara.Com/Mengapa-OrangMembuang-Sampah-Sembarangan. Mengapa Orang Membuang Sampah Sembarangan?. Diakses Pada 17 November 2021.

Https://Www.Bbc.Com/Indonesia/VertTra- 56743667. Singapura: Mengapa Menjaga Kebersihan Benar-Benar Jadi Kebiasaan Warga Negara-Kota Ini?. Diakses Pada 10 November 2021

Https://Money.Kompas.Com/Read/2009/1 2/0 3/21301549/ Regional Jawa.

Made. (2009). Penegakan Hukum Lingkungan Lemah. Diakses Pada 10
November 2021, Dari

Pinilih, S. A. G. (2015). Pelaksanaan Tugas dan Wewenang Badan Lingkungan Hidup Kota Semarang Dalam Penegakan Hukum Di Bidang Lingkungan. Notarius, 8(2), 236-251.

Rikin, A S. (2020). 2050, Diprediksi Laut Indonesia Dipenuhi Sampah. Diakses Pada 3 November 2021, Dari Https://Www.Beritasatu.Com/Nasion al/6003 30/2050-Diprediksi-LautIndonesia- Dipenuhi-Sampah

Rizal. (2017). Fungsi Pengawasan Pemerintah Kota Pekanbaru Terhadap Limbah Medis Balai Kesehatan/Poliklinik Di Kecamatan Tampan. Jurnal Renaissance. 2 (2), 270-277.

Subagiyo, H, Sembiring, R, Quina, M, Debora, A, Fatimah, I, Anindarini, G, Fadhillah, F.(2017). Buku Panduan Pengawasan Dan Penegakan Hukum Dalam Pencemaran Air. Cetakan Pertama. Indonesia Center For Environmental Law (Icel).

Undang-Undang Republik Indonesia Nomor 32 Tahun 2009 Tentang Perlindungan Dan Pengelolaan Lingkungan Hidup.

Undang-Undang No. 18 Tahun 2008 Tentang Pengelolaan Sampah.

Undang-Undang Dasar Republik Indonesia Tahun 1945

Wahyuni,T (2016). Indonesia Penyumbang Sampah Plastik Terbesar Ke- Dua Dunia. Diakses Pada 10 November 2021, Dari Https://Www.Cnnindonesia.Com/Gay a- $\quad$ Hidup/20160222182308-277112685/Indonesia-PenyumbangSampah- Plastik-Terbesar-Ke-DuaDunia. 
Wulandari, R. (2020). Perlu Bersegera Untuk Kurangi Produksi Dan Sampah Rumah Tangga. Diakses Pada 3 November 2021, Dari Https://Www.Mongabay.Co.Id/2020/ 09/09/P Erlu-Bersegera-UntukKurangi-Produksi- Dan-SampahRumah-Tangga/ 